\title{
A paradigm shift Changing approaches in the classroom
}

$\mathbf{F}_{\mathrm{s}}$ or most librarians, teaching is a major component of the job. Whether it be teaching a student to use a database during a reference session, leading a computer skills workshop at the public library, or providing information literacy instruction - in one form or another, at some point, a librarian is charged with imparting knowledge or skills to other people.

And yet, in my experience so far, the only real lesson we are concerned with imparting is that the library is a friendly place and librarians are approachable people. I learned from some of my mentors early on that if the only message that stuck with students after one of our brief information literacy sessions was to ask a librarian when they need help, we should be satisfied.

Imagine if you had a child in school and you found out that the only thing the teacher wanted them to learn was that teachers are willing to help you. Never mind that none of the students would pass their standardized tests; that is not much of an education.

But before you condemn the low teaching standards of librarians, remember that many of us are handicapped as teachers from the getgo. We often have much less face-time, struggle to make things like databases and keyword searching seem sexy, and have to battle our reputations as scary, shushing ogres. Not to mention that pedagogical theory is noticeably absent from most MLS programs.

And yet I began my first semester teaching a three-credit first-year seminar very confident of my skills as a teacher. With dozens of library instruction sessions under my belt, experience teaching Sunday school and preschool, and a big, juicy Master's degree to my name, I figured I was ready.
The first day of class went really well. I brought in coffee and donuts so we'd get off on the right foot and showed a picture of myself with bad '90s hair. I always liked it when my professors seemed like real people, and the first day of class is a good time to start building rapport. I left that class practically floating. My students were talkative, funny, attentive, and they laughed at my jokes! It was going to be a great semester.

Two days later, it's our second class meeting and I am wondering if alien body snatchers invaded and replaced my students with lower-energy models with a much diminished capacity for humor. They are tired and some of them already seem jaded by the whole first-year seminar experience.

My plan for this scenario had been to solider on briskly, maybe make them get up and do jumping jacks. Instead a strong librarian impulse overrode my logic, and I found myself smiling wider in a sort of desperate way and saying stuff like, "Hey could you guys look a little more bored and maybe give out a heaving sigh for me? I mean come on guys, perk up! This is hard work up here!" I could feel myself making that critical mistake of very obviously trying to please your students, when in fact they should be the ones trying to please you.

And the first time I tried to grade one of their assignments was traumatizing. My desire for them to succeed along with my librarian instincts made it painful to give anything less than a solid "B". In a reference interview, if you point

Mara Thacker is public services librarian at Paul Smith's College, e-mail:mthacker@paulsmiths.edu () 2012 Mara Thacker 
out that somebody is doing something wrong there is a chance you might discourage them from asking for help or using the library. You'd essentially be putting yourself out of business.

So, what to do? Well the first thing I did was talk to a few teaching mentors about some of the issues I was having. I can't stress enough to value of learning from someone who has "been there, done that." It was through one of these "teaching therapy" sessions that I was able to identify my problem of clashing professional identities. Since my performance feedback as a librarian has all been good so far, short of sparking a movement to change professional standards, I am left with changing my approach as a teacher.

Practically speaking, I need to start by defining my expectations and sticking to them. I should not lower my standards to meet my students; they need to rise to meet mine (provided my standards are reasonable in the first place). Of course I also can't expect my students to guess my standards, if I'm going to grade them fairly, I need to be extremely clear about what I expect. My rubrics have evolved from vague " 25 percent is format and 75 percent is content" statements to full-page documents with point-by-point breakdowns of all the minutiae.

As a librarian I would hate to be seen as a stickler or a hard-ass, but as a teacher the best way I can do my job and encourage my students to learn and grow is to demand high quality work and effort from them at all times. Like a physical trainer who demands one last push-up, I will demand that they write one more paragraph or read one more page-I will stretch them to their capacity, and at the end they will be stronger for it.

I will still make every effort to inject fun and joy in the classroom. Even the toughest physical trainers know that novelty, excitement, and enthusiasm are excellent motivators. But being popular and well-liked is on the back burner for the rest of the semester. It is more important that they respect me, learn from our experience together, and develop as young scholars. If they want gentle empathy, they can always come see me at the reference desk. $n$

\section{Have you visited the new Project MUSE?}

Project MUSE now offers both books and journals on a single new, fully-integrated platform. We provide:

- Over 15,000 digital scholarly books, side-by-side with more than 500 essential current journals in the humanities and social sciences

- New book titles released simultaneously with print

- A rich archive of past journal volumes and backlist books

- Affordable, flexible collections

- Unlimited usage, downloading, and printing; no DRM

- Easy-to-use tools for research and teaching

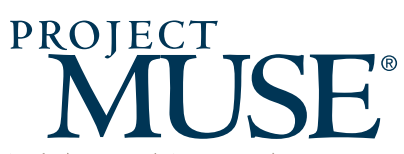

Today's Research. Tomorrow's Inspiration.

Take a tour: http://muse.jhu.edu

For more information: muse@press.jhu.edu 